\title{
CURRENT APPLICATION OF VITEX AGNUS-CASTUS L., BASED IN USES MENTIONED BY IBN RUSHD - A REVIEW
}

\author{
SULEIMAN OLIMAT* \\ Department of Medicinal Chemistry and Pharmacognosy, Faculty of Pharmacy, Jordan University of Science and Technology, \\ P. 0. Box 3030, Irbid 22110, Jordan. Email: smalkhalil@just.edu.jo
}

Received: 21 May 2020, Revised and Accepted: 16 June 2020

\section{ABSTRACT}

This is a specific review of Vitex agnus-castus L. (chasteberry) known as Finjinkest and Shajrat Ibrahim (Abraham's tree) in Arabic, focusing in the current application: V. agnus-castus is listed among other medicinal plants in the ancient book "Al-Kulliyat Fi A-Tibb," written by the famous Andulasin Philosopher Ibn Rushd. The focus of the study is to review only the uses mentioned in the book, review up to date literature (e.g., Google Scholar, PubMed, and Scopus) and analyzing the current pharmacological properties in link to the active constituents of the plant. The purpose of the present study is to confirm the uses of V. agnus-castus mentioned by Ibn Rushd with modern scientific and pharmacological research. Ethnopharmacological research confirming the uses mentioned by Ibn Rushd, such as treatment internal organs, liver and spleen, erectile dysfunction, and offspring. The results give further insights into the pharmacological activity of $V$. agnus-castus and confirm the different uses mentioned by Ibn Rushd.

Keywords: Vitex agnus-castus, Chasteberry, Past and current applications, Ibn Rushd.

(C) 2020 The Authors. Published by Innovare Academic Sciences Pvt Ltd. This is an open access article under the CC BY license (http://creativecommons. org/licenses/by/4. 0/) DOI: http://dx.doi.org/10.22159/ajpcr.2020.v13i9.38400

\section{INTRODUCTION}

The Andalusian philosopher Ibn Rushd (1128-1198 A.D.) known in the west by the name of Averroes. Ibn Rushd was a faithful disciple of Aristotle, and he stuck to the organization of the Aristotelian corpus implemented by Andronicus of Rhodes. He wrote many books in natural physics poets, Arabic literature, and philosophy, and in addition, one book in medicine known as "Kulliyat Fi A-Tibb, known in its Latin translation as Collige [1]. He mentioned plenty of plants used for the treatment of verities of diseases in different dosage forms following Galen in their applications [1,2]. Hippocrates, Dioscorides, and Theophrastus mention the use of Vitex agnus-castus for the treatment of amenorrhea, dysmenorrhea, to ease menopausal problems, hemorrhage following childbirth and the decoction of the herb and the seed was good for inflammations about the womb [2]. In this paper, I will focus on V. agnus-castus L. (Verbenaceae), commonly known as vitex, chaste tree, chasteberry (most popular), Abraham's balm, and monk's pepper, in Arabic known as Finjinkest and Shajrat Ibrahim (Abraham tree) [1]. Chasteberry is a shrub that can grow to a height of $6.71 \mathrm{~m}$, the plant comes from Southern Europe, Central Asia, and the Mediterranean area. It is also grown as an ornamental plant in the southern parts of North America. The medicinal parts used are the dried leaves and fruits, although the red-black berry is used too. The leaves contain the highest amount of flavonoids up to $2.7 \%$, with the blue-violet flowers a close second at $1.5 \%[3,4]$.

\section{USES OF CHASTEBERRY MENTIONED BY IBN RUSHD}

Ibn Rushed in his book "Kulliyat Fi A-Tibb (Colliget)" mentioned Finjinkest. "The drug has a strong, pungent taste with slight astringent. It has effects on cutting, brightening, and astringency, which has been used in the internal organs such as the liver and spleen. Its seeds cause erectile dysfunction and known as loss seeds. In general, its strength is the same strength as the Rue, but the Rue is much hotter than it and more drying and has no astringent effect. Known as the tree of loss: Because it loses the offspring by drying the semen [1]."

\section{CHEMICAL COMPOSITION OF CHASTEBERRY AND ITS MECHANISM OF ACTION}

Different classes of secondary metabolites that have been isolated from various parts of $V$. agnus-castus; fruits containing iridoids and iridoid glycosides (casticin, aucubin, and agnuside) [3,5]; flavonoids (apigenin, castican, orientin, penduletin, and isovitexin), flavonoid $O$ - or $C$-glycosides (orientin and vitexin); and flavonoids, luteolin 6-C-(4"-methyl-6"-0-trans-caffeoylglucoside), luteolin 6-C-(6"-0-transcaffeoylglucoside), luteolin 6-C-(2"-0-trans-caffeoylglucoside), and luteolin 7-0-(6"-p-benzoylglucoside) were isolated from the root bark of the plant., diterpenoids ( vitexilactone and rotundifuran), diterpene lactam (vitexlactam A); p-hydroxybenzoic acid $\beta$-sitosterol; and primary metabolites fatty acids (oleic acid, linolenic acid, palmitic acid, and stearic acid) [3,5-8]. Essential oils also presented in chasteberry (1,8-cineole, (E)- $\beta$-farnesene, (E)-caryophyllene, sabinene, limonene, cineol, and $\alpha$-terpinyl acetate were the major essential oils [9]. The current applications of $V$. agnus-castus are mainly to alleviate the premenstrual syndrome (PMS) symptoms that have been linked with a low level of progesterone relative to estrogen, so it is easy to see how chasteberry may help. Some studies have even shown benefits for women who suffer from menopausal symptoms or from fibrocystic breasts $[3,10,11]$. According to the best evidence, about $400 \mathrm{mg}$ of a powdered extract standardized to $0.5 \%$ agnuside is the appropriate daily dose [3]. Agnuside can affect hormone levels. While chasteberry contains no hormones, it can influence hormonal activity [12]. It turns out that chasteberry components can increase blood levels of progesterone. Chasteberry stimulates the pituitary to produce luteinizing hormone (LH) which, in turn, signals the ovaries to produce more progesterone [10]. The clinical efficacy of chasteberry is attributed to its effects on prolactin (PRL) secretion and dopamine receptors. The extracts of the fruits exerted dopaminergic $\left(D_{2}\right)$ receptor-binding activity in animal brain samples and inhibited the binding of the D-receptor ligand spiroperidole. Certain diterpenes (e.g., rotundifuran) also exerted such effects. V. agnus-castus extracts (and some diterpenes) inhibited PRL release [3,7,10-12]. The modern use of chasteberry dates back to the 1950s when the German pharmaceutical firm Madaus Company first produced a standardized extract. Agni casti fructus is official in the European Pharmacopoeia. It is application which is accepted for PMS by the European Medicines Agency $[3,12]$.

\section{THE PHARMACOLOGY OF V. AGNUS-CASTUS BASED ON IBN RUSHD USES (LIPIDO)}

The Latin name agnus-castus means chaste lamb, which may refer to the libido-reducing effect of the seeds. The name is thought to come 
from a belief that the plant promoted chastity. For this presumed effect, berries of chasteberry suppress the libido in both men and women. It is reported that monks in the middle ages chewed the berries to decrease sexual desire $[11,13,14]$. In Iranian folk medicine, chasteberry is used in the reduction of libido [13]. Other species Vitex negundo (Nirgundi) are found in Eastern Africa, Iran, Burma, Japan, Pakistan, India, Sri Lanka, China, and South Asian countries, also known by the name monk's berry or monk's pepper because, in ancient times, monks were used to chew the berries of $V$. negundo to reduce their sexual desire [15]. It is recorded that Roman wives, whose husbands were abroad with the legions, spread the aromatic leaves on their couches to reduce sexual desire $[13,15]$. There are no clinical data to support the use of chasteberry for reducing sexual desire, which has been a traditional application [11-15]. Ibn Rushed mentioned that chasteberry is known as the tree of loss because it loses the offspring by drying the semen [1]. On the other hand, he mentioned: "the plant celebrated by women in ancient Greek festivals and on holy days as a symbol of marriage, chastity, and fertility, by spreading it under their bed [1]." V. agnus-castus may be recommended for several female sexual dysfunction (FSD), which associated with the decline of estrogen, menopause is a critical phase for FSD complaints [16]. Animal and human studies have shown that extracts of chasteberry tree berries bind to dopamine receptors in the anterior pituitary and decrease both basal and thyrotropin-releasing hormone-stimulated secretion of immunoreactive PRL [17]. Agnuside, the standard reference compounds in chasteberry, can affect hormone levels, the plant does not contain hormones, it can influence hormonal activity by increase blood levels of progesterone by stimulates the pituitary to produce LH which, in turn, signals the ovaries to produce more progesterone [18]. The libidoregulating properties of anaphrodisiacs seem to be associated with sedative and toxic effects or decreasing testosterone levels. $\mathrm{CB}_{2}$ receptors expressed on dopaminergic neurons of the ventral tegmental area, part of the brain's reward circuit, chasteberry has been used to normalize hormones in both men and women, this is due to the presence of essential oil, and mainly, $\beta$-caryophyllene might have the anaphrodisiacs potential effect $[11,13,14]$. Dioscorides mentioned that the decoction of the herb and the seed was good for inflammations about the womb and, when used in sits baths, found suitable for diseases of the uterus (endometriosis) and female infertility [11,14]. Preliminary studies have shown that extracts of $V$. agnus-castus can stimulate the release of $\mathrm{LH}$ and inhibit the release of follicle-stimulating hormone (FSH) $[2,4]$. Evaluation the effects of $V$. agnus-castus fruit extract on the activity of pituitary-gonadal axis in male mice. The blood samples collected and measured FSH, LH, and testosterone. Vitex extract decreased the FSH, $\mathrm{LH}$, and testosterone levels comparing to the control and sham groups. These results suggest that Vitex. fruit extract has an antiandrogenic effect and probably acts through the hypothalamic pituitary-gonadal axis $[12,13]$. I think that modern science has shown that the monks might be wrong, chasteberry does not interfere with the sex drive. In conclusion, there is a contra-orthodox result to support that V. agnuscastus reduces sex desire [11].

\section{THE PHARMACOLOGY OF CHASTEBRRY BASED ON IBN RUSHD USES ( LIVER AND SPLEEN)}

Liver is a fatal organ in and very important for the body functioning. Early liver disease may have minimal or no symptoms, as liver disease progresses, characteristic signs develop. These signs can include a yellow tone to the skin and whites of eyes (jaundice) and brownish urine and lead to cirrhosis, the abdomen becomes distended with fluid (ascites) and ruptures blood vessels in the stomach and esophagus cause bleeding. The person may vomit blood or pass black stools [19]. The spleen is a secondary lymphoid organ which can influence the progression of multiple diseases, notably liver fibrosis to cirrhosis. In chronic liver diseases, splenomegaly and hypersplenism can manifest following the development of portal hypertension [20]. V. agnus-castus was mentioned by Ibn Sina, (Avicenna, 980-1037 AD) for the treatment of kidney and spleen in his famous medical book Al-Qānūn fi Tibb (Canon) [21]. Viral infection (Hepatitis A, B, and C) where not known clearly for ancient physicians, only known as liver disorders. Ibn Rushd mentioned chasteberry for treatment of liver and spleen but without mention the symptoms or the kind of disease affecting those organs [1]. Lipid metabolism and nonalcoholic fat liver disease (NAFLD) frequently associated with menopause. Ovariectomized rats exhibit increased adiposity and NAFLD. Experimental animals, rats, were treated with crude extract and a butanolic fraction of $V$. agnus-castus and displayed the beneficial effects of a reduction in the adiposity index and a complete reversion of NAFLD. NAFLD reversion was accompanied by a general improvement in the liver redox status. It can be concluded that both fractions from $V$. agnus-castus were effective in preventing NAFLD and oxidative stress, which are frequent causes of abnormal liver functions in the postmenopausal period [22,23]. V. agnus-castus showed hepatoprotective activity [24]. There is no clinical or scientific research concerning the effect of $V$. agnus-castus on the spleen.

\section{CONCLUSION}

Modern ethnopharmacology validated some of the uses of $V$. agnuscastus (chasteberry) mentioned by Ibn Rushd.

\section{ACKNOWLEDGMENT}

I would like to thank the librarians at the library of Jordan University of Science and Technology for their great help during the preparation of this manuscript.

\section{CONFLICTS OF INTEREST}

The author has stated that there are no conflicts of interest associated with the publication and no financial support, which could have influenced the outcome.

\section{REFERENCES}

1. Al-Jabiry A. Ibn Rushd, Al-Kulliyat Fi A-Tibb. Beirut, Lebanon: Center for Arab Unity Studies; 1999.

2. Vassilliadis S. De materia medica versus codex alimentarius for the reinforcement of the gynecologic immune system: The case of endometriosis. Clin Med Insights Womens Health 2013:6:31-5.

3. Csupor D. Phyotherapy: A Textbook for Pharmacy Students. Szeged, Hungary: University of Szeged Press; 2105. p. 148.

4. Rani A, Sharma A. The genus Vitex: A review. Pharmacogn Rev 2013;7:188-98

5. Rajanna L, Raghavan V, Sharma S. Phytochemical evaluation of Vitex agnus-castus L seeds collected from different geographical regions of the world. Res Rev 2015;4:21-8

6. Stojković D, Soković M, Glamočlija J, Džamić A, Ćirić A, Ristić M, et al. Chemical composition and antimicrobial activity of Vitex agnuscastus L. fruits and leaves essential oils. Food Chem 2011;128:1017-22.

7. Ibrahim NA, Shalaby AS, Farag RS, Elbaroty GS, Nofal SM, Hassan EM, et al. Gynecological efficacy and chemical investigation of Vitex agnus-castus L. fruits growing in Egypt. Nat Prod Res 2008;22:537-46

8. Hirobe C, Qiao ZS, Takeya K, Itokawa H. Cytotoxic flavonoids from Vitex agnus-castus. Phytochemistry 1997;46:521-4.

9. Goncalves R, Ayres VF, Souza MG, Guimarães AC, Corrêa GM, Martins $\mathrm{CH}$, et al. Chemical composition and antibacterial activity of the essential oil of Vitex agnus-castus L. (Lamiaceae). Ann Acad Bras Ciênc 2017;89:1-9.

10. Schellenberg R. Treatment for the premenstrual syndrome with agnus castus fruit extract: Prospective, randomised, placebo controlled study. BMJ 2001;322:134-7.

11. Roemheld B, Hamm O. Chasteberry. Am Fam Physician 2005;72:821-4.

12. Atmaca M, Kumru S, Tezcan E. Fluoxetine versus Vitex agnus-castus extract in the treatment of premenstrual dysphoric disorder. Hum Psychopharmacol 2002;18:191-5.

13. Emad K, Saiah GV, Hasannejad H, Ghaderi A, Ghaderi S, Hamidian G, et al. Antinociceptive effects, acute toxicity and chemical composition of Vitex agnus-castus essential oil. Avicenna J Phytomed 2015;5:218-30.

14. Mahady GB, Dietz B, Engle J. Chasteberry (Vitus agnus-castus). In: Cotes P, Blackman M, Cragg G, Levine M, Moss J, White J, editors. Encyclopedia of Dietary Supplements. New York: Marcel Dekker; 2004. p. 95-101.

15. Vimal A, Lohar V, Singhal S, Anil B. Vitex negundo: A Chinese chaste 
tree. Int J Pharm Innov 2011;1:9-20.

16. Mazaro-Costa R, Andersen ML, Hachul H, Tufik S. Medicinal plants as alternative treatments for female sexual dysfunction: Utopian vision or possible treatment in climacteric women? J Sex Med 2010;7:3695-714.

17. Haider A, Spellman C, Mok M. Prolactin-secreting microadenoma masked by a herbal product, Vitex agnus-castus. AACE J 2017;3:51-3.

18. Available from: https://www.mcgill.ca/oss/article/health-supplementsyou-asked/you-asked-does-chasteberry-curb-sex-drive.

19. Available from: https://www.my.clevelandclinic.org/health/ diseases/17179-liver-disease.

20. Li L, Duan M, Chen WE, Jiang A, Li X, Yang J, et al. The spleen in liver cirrhosis: Revisiting an old enemy with novel targets. J Transl Med 2017; $15: 1-10$

21. Pour M, Mirazi N, Seif A. Treatment of liver and spleen illnesses by herbs: Recommendations of Avicenna's heritage "canon of medicine". Avicenna J Phytomed 2019;9:101-16.

22. Nasri S, Oryan1 S, Rohani AH, Amin GH, Yahyavi H. The effects of Vitex agnus-castus L. extract on gonadotrophines and testosterone in male mice. Iran Int J Sci 2004;5:25-30.

23. Moreno FN, Campos-Shimada LB, da Costa SC, Garcia RF, Cecchini AL, Natali MR, et al. Vitex agnus-castus L. (Verbenaceae) improves the liver lipid metabolism and redox state of ovariectomized rats. Evid Based Complement Altern Med 2015;2015:212378.

24. Ali M, Khan T, Fatima K, Ul Ain Ali Q, Ovais M, Khalil AT, et al. Selected hepatoprotective herbal medicines: Evidence from ethnomedicinal applications, animal models, and possible mechanism of actions. Phytother Res 2018;32:199-215 